\title{
Community perceptions of collaborative processes for managing freshwater resources
}

$\underline{\text { Jim Sinner }}^{1}, \underline{\text { Philip Brown }}^{2}$ and $\underline{\text { Mark Newton }}^{1}$

\begin{abstract}
Six of New Zealand's 16 regional councils are trialling collaborative planning as a means of addressing complex challenges in freshwater management. Although some work has been undertaken to evaluate similarities and differences across those processes, the success or failure rests with the public's acceptance of the processes and their outcomes. This is the first study to evaluate public perceptions of freshwater management in regions with collaborative processes. We surveyed 450 respondents in Hawke's Bay, Northland, and Waikato, some of whom live in catchments in which collaborative processes are under way and some of whom do not. In addition to assessing awareness of the collaborative planning processes, the survey measured perceptions regarding the regional council's management of freshwater resources, the extent of agreement regarding freshwater management among various interests, the fairness of freshwater management, and the extent to which respondents believe that their interests and concerns are included in freshwater management. We hypothesized that relative to respondents in parts of the region in which traditional processes are in places, respondents in catchments with collaborative management of freshwater resources would have more positive perceptions of management, agreement, fairness, and interests, even if there is low awareness that a collaborative planning process is under way. Survey results indicate that knowledge of collaborative processes is generally low and that living in catchments with collaborative processes does not impact respondents' perceptions of management, agreement, fairness, or interests in Northland or Waikato. However, relative to Hawke's Bay respondents living outside of the collaborative catchment, respondents living inside the collaborative catchment believe that the regional council's freshwater management is better and fairer. Moreover, Hawke's Bay residents living inside the collaborative catchment perceive less conflict over freshwater management than Hawke's Bay respondents living outside the collaborative catchment. Further research is needed to identify the reasons for this regional variation.
\end{abstract}

Key Words: environment; local government; natural resources; New Zealand; public perceptions

\section{INTRODUCTION}

Collaborative planning engages parties in decision-making processes to achieve joint learning, to build capacity for problem solving and adaptation, and to generate more durable solutions for the wider community (Innes and Booher 2010). These approaches are well suited to resolving complex challenges in environmental planning (Dietz et al. 2003, Ansell and Gash 2008, Innes and Booher 2010), particularly for freshwater management (Scholz and Stiftel 2005, Pahl-Wostl et al. 2008).

Freshwater management in New Zealand faces complex challenges: Land use intensification, increasing demand for water, and an ever-more-numerous, invested, and diverse array of stakeholders have brought mounting conflict (MfE 2013). In 2013, water-related issues were cited by $28 \%$ of New Zealanders as the most important environmental issue facing the country, on par with climate change, which was rated by $28 \%$ as the most important global issue. Agriculture was the next highest domestic issue, at 8\% (Hughey et al. 2013).

New Zealand's National Policy Statement for Freshwater Management (NPSFM), issued in 2011 and updated in 2014 (MfE 2014), sets out objectives and policies for freshwater management to provide national consistency in local planning and decision making while allowing for regional flexibility. Under the NPSFM, regional councils, i.e., local governments, are required to set objectives for freshwater bodies that reflect national and local values and to set flow, allocation, and water-quality limits to ensure that those objectives are achieved. Regional councils are primarily resource-management agencies with responsibility for managing the effects of land use and other activities on water, air, and the coast.
The standard process for regional planning in New Zealand involves councils producing draft plans and inviting submissions, followed by public hearings, council decisions, and appeals to the Environment Court. Collaborative approaches differ in that multistakeholder groups are convened to recommend the policies included in the draft plans, with a strong emphasis on consensus. Under existing law, however, the council must still issue a draft plan, call for submissions, hold hearings, and exercise its own judgments, which are then subject to appeal. The central government has proposed legislative amendments to enable regional councils to limit appeal rights if they choose collaborative freshwater decision making and meet certain requirements (MfE 2013). The proposed amendments were introduced to Parliament in November 2015, by which time regional councils in Canterbury, Hawke's Bay, Northland, Tasman, Wellington, and Waikato were already using collaborative approaches to freshwater planning (Land and Water Forum 2012).

Sinner et al. (2015) conducted three focus groups in Canterbury to explore whether engagement of an individual or group in collaborative freshwater planning affects perceptions of the legitimacy of that process. Among focus group participants who had participated in planning processes, those affiliated with environmental, recreational, and community groups held negative perceptions about the transparency, accountability, and representativeness of the processes. In contrast, those from farming backgrounds were more likely to positively assess collaborative decision making. Individuals who had no involvement in collaborative processes had very little awareness that a collaborative process was under way, although they were unanimously sceptical that their views and interests were 
Fig. 1. New Zealand. The three regions under study are highlighted.

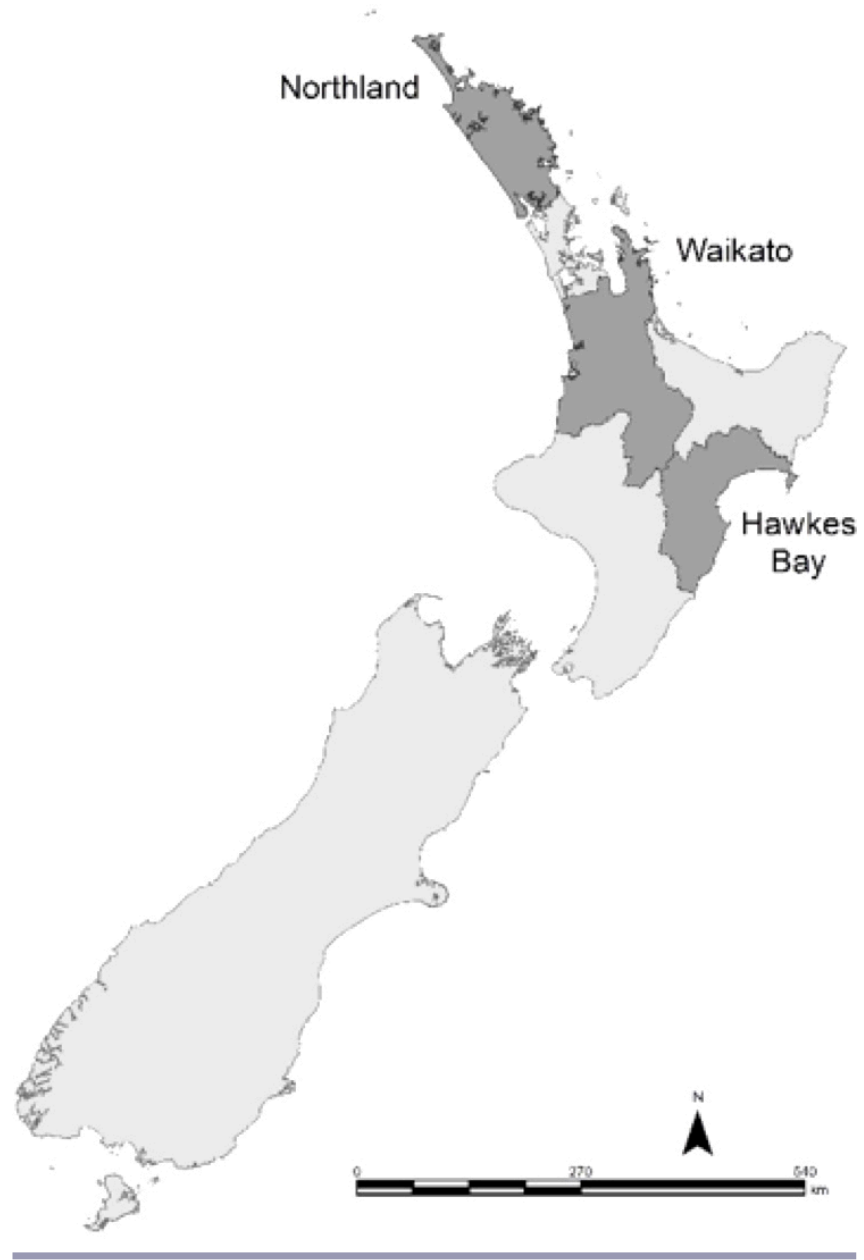

represented, and many were upset at their perceived exclusion. Sinner et al. conclude by recognizing the need to explore community perceptions of collaborative freshwater planning with a larger sample across multiple regions.

The objective of this study was thus to assess how collaborative planning processes influence the perceptions of the wider community. In particular, we were interested in perceptions of management quality, the degree of conflict over freshwater management, the fairness of water management, and how well people feel that their interests are represented and taken into account by the regional council.

We expected that catchments in which collaborative processes are successful would have more positive, or at least less negative, media coverage about freshwater management. We thus hypothesized that in such situations, the wider community would have more positive perceptions of freshwater management, would tend toward a perception of agreement about freshwater management (as opposed to conflict), and would have a greater sense that the process is fair. We also hypothesized that they would be more likely to believe that their interests with regard to
Fig. 2. Hawke's Bay. The Tūtaekuri, Ahuriri, Ngaruroro and Karamū catchments are highlighted.

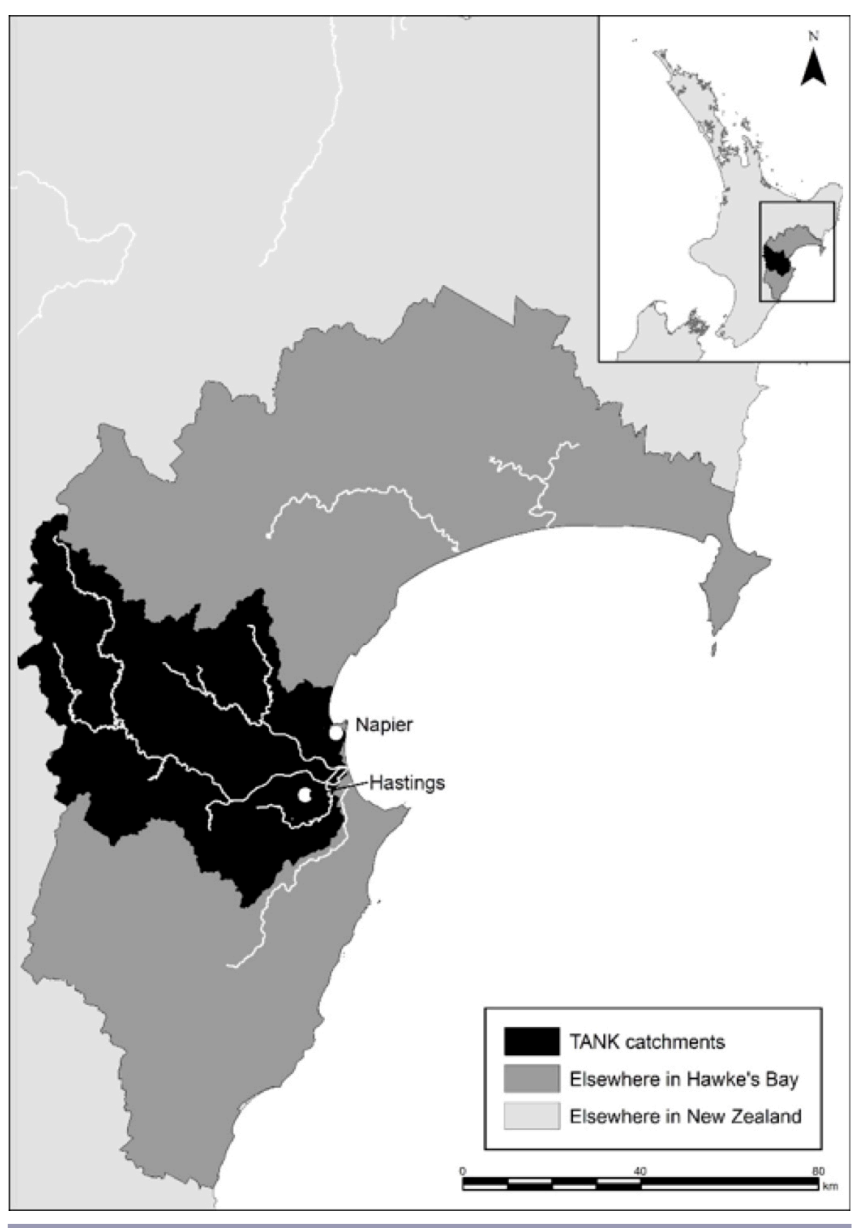

freshwater are taken into account by the regional council. We expected these hypotheses to hold even if there is low awareness that a collaborative planning process is under way. Furthermore, we expected change over time as collaborative processes work toward and achieve consensus.

\section{SCOPE}

This analysis focuses on three New Zealand regions that are currently using collaborative planning for freshwater management in one or more catchments: Hawke's Bay, Northland, and Waikato (Fig. 1). The selected regions all had collaborative processes that had been under way for between one and three years at the time of our survey. The only region with longer running collaborative freshwater planning processes is Canterbury, where public perceptions are confounded by central government replacement of elected regional councillors with appointed commissioners in 2009.

In Hawke's Bay, the regional council is reviewing the management of land and water in the Tutaekuri, Ahuriri, Ngaruroro, and Karamū (TANK) catchments, in which more than $85 \%$ of the region's population lives and works (Fig. 2). A collaborative stakeholder group (hereafter, the TANK Group) was established 
Fig. 3. Northland. The Mangere, Waitangi, Doubtless Bay, Whāngārei, and Pouto Lakes catchments are highlighted.

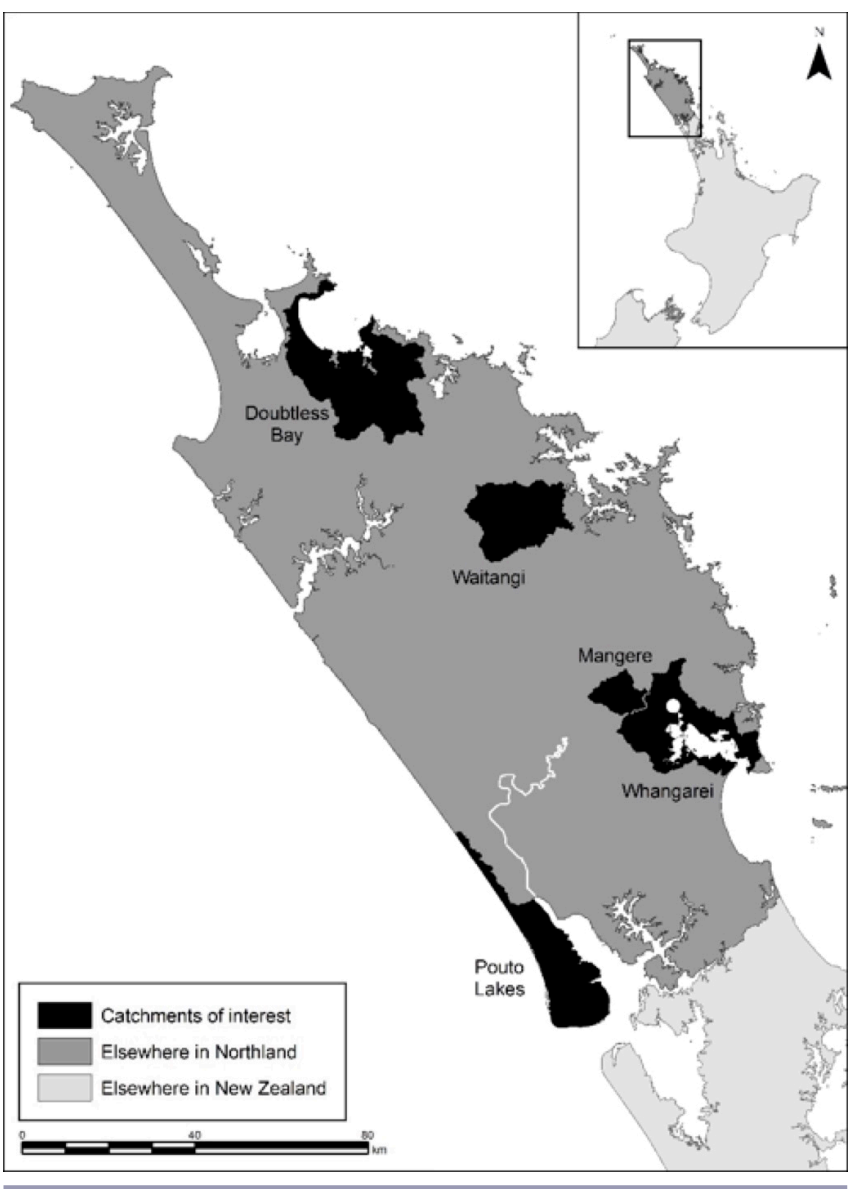

in 2012 to make recommendations for a plan change to implement the Hawke's Bay Land and Water Management strategy and the NPSFM. ${ }^{[1]}$ It consists of 30 people representing a broad range of interests including horticulture, pastoral farming, environment, recreation, forestry, and iwi/hapū (tribes and clans of Māori, the indigenous people of New Zealand). It focuses on water quality, flows, and allocations (HBRC 2015), and the Hawke's Bay Regional Council has made "a good faith commitment to support any consensus recommendations from the TANK Group" (HBRC 2015). The TANK Group is aiming to finish its recommendations by October 2017 (HBRC 2015).

Collaborative freshwater planning in Northland began in 2012 with the Waiora Northland Water programme, under which the Northland Regional Council collaborates with communities to give effect to the NPSFM. The council initiated collaborative processes in five catchments (Mangere, Waitangi, Doubtless Bay, Whāngārei, and Pouto Lakes; Fig. 3); a sixth catchment (Ngunguru) was added after this research was undertaken.

In each area, a collaborative stakeholder group, i.e., a catchment group, provides local input on maintaining and improving the state and management of the catchment's fresh water, works with Northland Regional Council to deliver the Waiora Northland
Fig. 4. Waikato. The Waikato and Waipa catchments are highlighted.

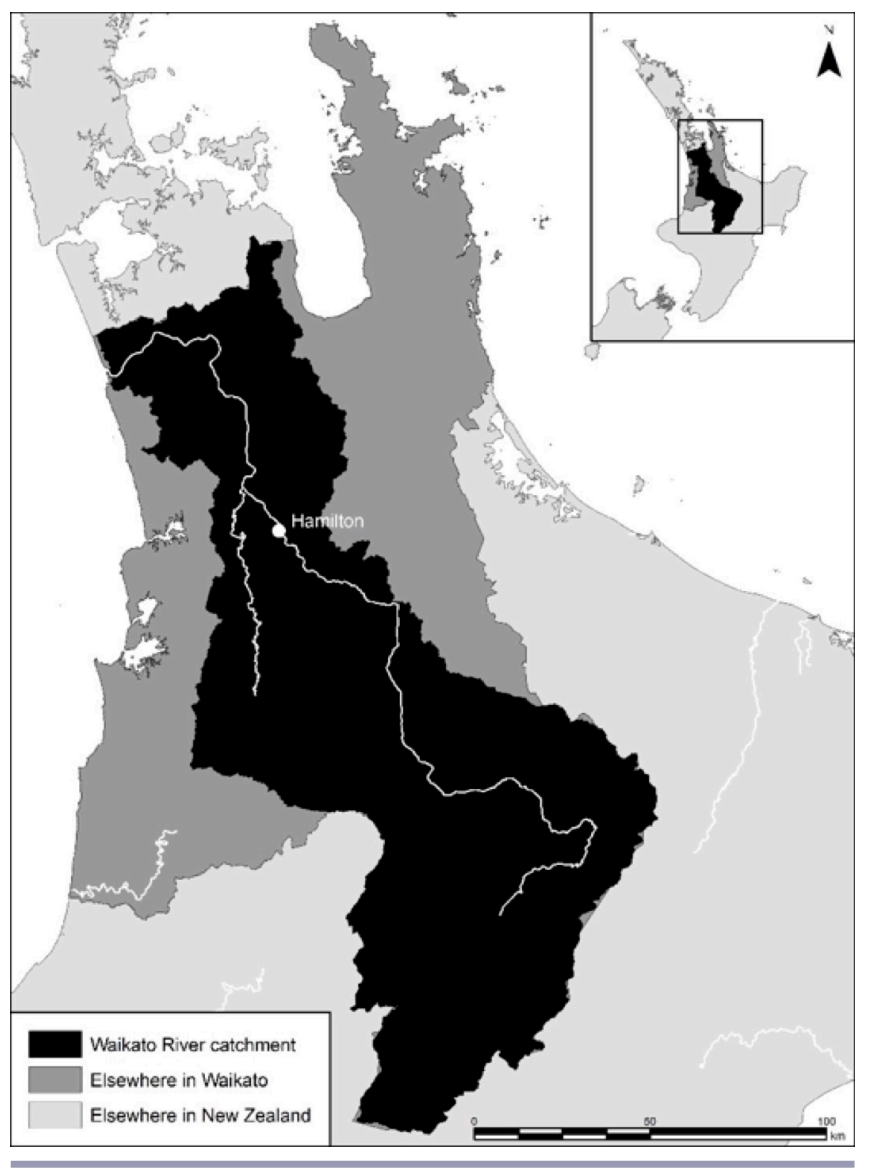

Water program, develops objectives and policies for the Water and Soil Plan for Northland, and engages with wider networks to share information. The catchment groups comprise representatives nominated by a range of local interests, e.g., iwi/ hapū, landowners, industry, environmental groups, recreational users, and councils. Decisions are made by consensus. The Northland Regional Council released draft catchment plans for public feedback in mid-2016 and expects to issue proposed rules for formal submissions in 2017.

Operating under comanagement legislation implemented to settle Treaty of Waitangi claims, the Waikato Regional Council and local iwi/hapū have established Healthy Rivers: Plan for Change/ Wai Ora: He Rautaki Whakapaipai, which is tasked with making recommendations to reduce inputs of sediment, bacteria, and nutrients to restore the health of the Waikato and Waipa rivers (WRC 2015; Fig. 4). This collaborative stakeholder group has 17 sector representatives representing dairy, horticulture, energy, environment, tourism, forestry, and iwi/hapū, and 7 community representatives. Most sectors nominated their own representatives, whereas a selection panel for the project chose the community representatives and the remaining sector representatives. The group approved a report outlining its recommendations for water quality objectives and limits in March 2016, and the council aims to announce proposed rule changes by July 2016 . 


\section{METHODS}

To evaluate attitudes toward collaborative processes for freshwater management, we undertook a telephone survey of the general public in Hawke's Bay, Northland, and Waikato in May 2015. In each region, two populations were surveyed: those from catchments in which a collaborative freshwater planning process is under way and those from other catchments within the region. This approach was selected to control for regional variation in underlying attitudes toward the council (N. A. Cradock-Henry, S. Greenhalgh, P. Brown, and J. Sinner, unpublished manuscript).

In the control catchments, significant traditional planning processes have been undertaken within the past several years. In Waikato, appeals on a contentious region-wide water allocation plan were resolved in 2012, six years after the process started (WRC 2016). In Hawke's Bay, an acrimonious planning process in a catchment without a collaborative process involved hearings in late 2013 and early 2014. Appeals were decided in 2015, although legal skirmishes continue (Environmental Protection Authority 2015). In Northland, a region-wide planning process involved hearings in 2013 and council decisions in 2014 followed by appeals. Mediation took place in 2015 (including the period of our survey), and all but one appeal has since been resolved (Northland Regional Council 2016).

The survey design was informed by the preliminary findings of Sinner et al. (2015) and a literature review of collaborativeplanning processes (Cradock-Henry 2013). Our questions concern perceptions of the wider community, namely, perceptions of how well the regional council manages fresh water, the perceived fairness of water management, perceptions of conflict vis-à-vis agreement over water management, and how well a person's interests and concerns are taken into account.

Telephone interviews were conducted with approximately 30 respondents in each of the 5 catchments with collaborative processes in Northland, approximately 60 respondents in the Waikato River catchment, approximately 60 respondents in the TANK catchments in Hawke's Bay, and approximately 180 respondents from elsewhere in those regions (approximately 60 in each). The total sample size was 450 respondents.

Surveys conducted via telephone are subject to known limitations. First, response rates to telephone surveys are low, such that those who agree to complete surveys may not be representative of the wider population. More importantly, a growing number of households lack landlines (Kempf and Remington 2007, Link et al. 2007). The results must be interpreted in this light.

Four questions were used to assess the effects of collaboration on public perceptions. Specifically, the survey asked the following:

- Using a scale from 0 to 10 , where 0 means very poorly and 10 means very well, in your opinion, how well does the regional council manage freshwater bodies? (Management)

- Thinking about conflict or agreement between competing interests over water management in your area, using a scale of 0 to 10 where 0 means lots of conflict and 10 means strong agreement, would you say there is conflict or agreement between competing interests over water management in your area? (Agreement)

- Using a scale from 0 to 10, where 0 means not fair at all and 10 means very fair, in your opinion, how fair do you think the water management processes are in the [name of region] regional council area? (Fairness)

- Using a scale from 0 to 10 , where 0 means not confident at all and 10 means very confident, if you had concerns about how you, your family, or your business was affected by freshwater management, how confident are you that your interests and concerns would be taken into account by the regional council? (Interests)

We used multivariate regression to identify whether differences in responses were correlated with collaborative planning and other variables. Because the answer set for each question is censored at 0 and 10 , we specified a Tobit functional form. That is:

$$
\begin{gathered}
y_{i j}^{*}=\alpha_{1} R_{j}+\alpha_{2} P+\alpha_{3}\left(R_{j} \times P\right)+x_{i}^{\prime} \beta \\
+u_{i j}, u \sim N\left(0, \sigma^{2}\right)
\end{gathered}
$$

where $y_{i j}^{*}$ is a latent variable equal to the observed variable, $y_{i j}$, only when the latent variable for respondent $i$ in region $j$ falls between the values of 0 and $10 . R_{j}$ indicates the region of residence and $P$ indicates whether the individual resides in a catchment with a collaborative process. $\mathbf{x}$ is a vector of control variables, including gender, ethnicity, current/previous employment in related areas, and engagement with freshwater planning. Gender is measured via a dummy for female; ethnicity is measured via a dummy for Māori; employment is measured via separate dummies for having worked in farming, forestry, water/environmental management, and government; and engagement is measured via a dummy to indicate whether respondents made submissions or attended meetings/hearings about freshwater management. The error term, $u$, is normally distributed. Thus, we have:

$$
y_{i j}=\left\{\begin{array}{c}
10 \text { if } y_{i j}^{*} \geq 10 \\
y_{i j}^{*} \text { if } 0<y_{i j}^{*}<10 \\
0 \text { if } y_{i j}^{*} \leq 0
\end{array}\right.
$$

In contrast to the ordinary least squares (OLS) method with censored data, the Tobit estimator is consistent (Amemiya 1973). (Results obtained via OLS are nevertheless broadly consistent with the results presented here.) The coefficients are interpreted similarly to OLS regression coefficients, although the linear effect in the Tobit model is on the uncensored latent variable, not the observed outcome.

\section{RESULTS}

\section{Summary statistics}

Some $53 \%$ of the 120 respondents living in Hawke's Bay reside in catchments with collaborative processes (Table 1), as do $59 \%$ of 210 respondents in Northland and $54 \%$ of the 120 respondents in Waikato. Overall, of survey respondents in areas with collaborative processes, 21\% were aware (correctly) that collaboration is taking place while $15 \%$ of respondents in areas without collaborative processes incorrectly thought that a collaborative planning process is taking place. Approximately half of respondents were male, and survey respondents identified as New Zealand European (84\%), Māori (14\%), or Pacific Island, Asian, and other ethnicities (2\%). 
Table 1. Summary statistics

\begin{tabular}{lccc}
\hline \hline & Hawke's Bay & Northland & Waikato \\
\hline Collaborative catchment & $53.3 \%$ & $58.6 \%$ & $54.2 \%$ \\
Female & $54.2 \%$ & $44.3 \%$ & $52.5 \%$ \\
Māori & $9.2 \%$ & $17.1 \%$ & $11.7 \%$ \\
Employment: farming & $28.3 \%$ & $47.6 \%$ & $33.3 \%$ \\
Employment: forestry & $4.2 \%$ & $10.5 \%$ & $5.8 \%$ \\
Employment: water/ & $5.8 \%$ & $7.1 \%$ & $5.8 \%$ \\
environment & & & \\
Employment: government & $5.8 \%$ & $7.6 \%$ & $5.8 \%$ \\
Medium/high engagement & $30.0 \%$ & $22.9 \%$ & $21.7 \%$ \\
\hline
\end{tabular}

Unit $=1 / 0$.

Survey respondents were asked if they are currently/previously employed in several sectors that have an interest in freshwater management. Some 39\% reported employment in farming, followed by construction/civil planning $(9 \%)$, forestry $(8 \%)$, central or regional government $(7 \%)$, environmental management $(5 \%)$, and water management $(10 \%)$, with the remaining $22 \%$ either employed in other industries or unemployed. Employment data from Statistics New Zealand suggest that the sample may have had some self-selection bias toward those with a greater interest in freshwater management because farmers represent $15 \%-17 \%$ of the population in each of these three regions. Moreover, the Statistics New Zealand category "other services," which includes government and environmental and water management, accounts for about $11 \%$ of employment across New Zealand. That being said, Statistics New Zealand collects data on current occupations whereas our data reflect both current and former occupations.

Survey respondents also reported their engagement in freshwater planning via participation in related activities. Two-thirds of respondents reported reading articles about water management, and more than half reported discussing water issues with others. We classified respondents who participate in one or both of these activities but no others as having low engagement in freshwater planning. The next most common forms of involvement were attending a public meeting $(10 \%)$, contacting local or central government $(10 \%)$, participating in a meeting of industry $(7 \%)$, and participating in a meeting sponsored by a nongovernmental organization $(12 \%)$. Participants who reported at least one of these were categorized as having medium participation unless they also made a submission about water management issues to central government/regional councils $(5 \%)$ or spoke at a regional council hearing about water management issues $(3 \%)$, in which case they were categorized as having high participation. Overall, $30 \%$ of the respondents in Hawke's Bay, 23\% in Northland, and 22\% in Waikato had medium or high participation levels; those who had actively participated in water management may have been more likely to agree to take part in the survey.

\section{Management}

We hypothesized that collaboration would result in less conflict and less adverse publicity, and hence higher perceptions of councils' management of freshwater. Nevertheless, we acknowledge that councils may prioritize collaborative approaches in catchments that have more difficult issues, which could also lead to lower perceptions in collaborative catchments, at least initially. Table 2 reports the estimates for the determinants of perceptions of the regional council's management of freshwater as per equation 1 .

The sole regressor in the first model is whether the individual resides in a catchment with a collaborative process. Model 2 adds region dummies, and model 3 adds interaction terms. Model 4 adds employment categories, whereas model 5 adds demographic variables. Model 6 extends model 5 by including engagement in freshwater planning as an additional regressor. Heteroskedasticityrobust $t$ statistics are reported in parentheses. McFadden's pseudo $\mathrm{R}^{2}$ statistic is also reported for each model; based on this measure, our discussion focuses on model $6 .^{[2]}$

For models with the (region $\mathrm{x}$ collaborative catchment) interaction term, the marginal effect of living in a catchment with a collaborative process vis-à-vis living in the same region but in a catchment without a collaborative process is shown below the constant. The statistical significance of these marginal effects was calculated via $\mathrm{F}$ tests.

Among respondents living outside catchments with collaborative processes in Waikato, the estimated subjective evaluation of the regional council's management of freshwater was 5.2. The views of those living in catchments with collaborative processes did not differ in a statistical sense from the views of those living in catchments without collaborative processes. Northland respondents evaluated their council lower than Waikato respondents $(\mathrm{p}<0.10)$, with no discernible difference for those living inside collaborative catchments. Hawke's Bay respondents without collaborative processes did not evaluate their council's management differently from Waikato respondents without collaborative processes. However, Hawke's Bay respondents living in catchments with collaborative processes scored the management performance of their council 0.9 points higher than those living elsewhere in Hawke's Bay $(\mathrm{p}<0.10)$.

Māori respondents rated their regional council's management statistically lower than non-Māori respondents ( $\mathrm{p}<0.10 \mathrm{in} \mathrm{model}$ 5). Engagement was also negatively correlated with subjective evaluation of the regional council's management performance, with respondents who were engaged at a medium or high level scoring their regional council's performance 0.8 points lower, on average $(\mathrm{p}<0.01)$. This result may stem either from engaged respondents having more intimate knowledge of their council's management performance or from their becoming engaged because they are unsatisfied with that performance.

\section{Agreement}

We hypothesized that collaborative processes would help to ameliorate perceptions of conflict and promote perceptions of agreement among various interests in water management. Table 3 reports the estimates for the determinants of perceptions of agreement as per equation 1. Variations on the model were undertaken as above. Again, model 6 is the preferred specification.

Respondents from Hawke's Bay catchments without collaborative processes were estimated to rate the extent of agreement 1.54 points lower than respondents from Waikato catchments $(\mathrm{p}<.01)$, which is $28 \%$ of the mean. This negative perception was less severe among Hawke's Bay residents in collaborative catchments. 
Table 2. Perceptions of regional councils' management ("Using a scale from 0 to 10 , where 0 means very poorly and 10 means very well, in your opinion how well does the [name of regional council] manage freshwater bodies?")

\begin{tabular}{|c|c|c|c|c|c|c|}
\hline & (1) & (2) & (3) & (4) & (5) & (6) \\
\hline Collaborative catchment & $\begin{array}{l}0.128 \\
(0.44)\end{array}$ & $\begin{array}{l}0.163 \\
(0.56)\end{array}$ & $\begin{array}{l}-0.647 \\
(-1.16)\end{array}$ & $\begin{array}{l}-0.706 \\
(-1.25)\end{array}$ & $\begin{array}{l}-0.678 \\
(-1.22)\end{array}$ & $\begin{array}{l}-0.743 \\
(-1.34)\end{array}$ \\
\hline Northland & & $\begin{array}{l}-0.252 \\
(-0.70)\end{array}$ & $\begin{array}{l}-0.769 \\
(-1.61)\end{array}$ & $\begin{array}{l}-0.932 * \\
(-1.85)\end{array}$ & $\begin{array}{c}-0.837^{*} \\
(-1.67)\end{array}$ & $\begin{array}{c}-0.880^{*} \\
(-1.73)\end{array}$ \\
\hline Hawke's Bay & & $\begin{array}{l}0.477 \\
(1.23)\end{array}$ & $\begin{array}{l}-0.263 \\
(-0.49)\end{array}$ & $\begin{array}{l}-0.356 \\
(-0.66)\end{array}$ & $\begin{array}{l}-0.396 \\
(-0.74)\end{array}$ & $\begin{array}{l}-0.305 \\
(-0.57)\end{array}$ \\
\hline Northland $\mathrm{x}$ collaborative & & & $\begin{array}{l}0.935 \\
(1.32)\end{array}$ & $\begin{array}{c}1.001 \\
(1.41)\end{array}$ & $\begin{array}{l}0.968 \\
(1.37)\end{array}$ & $\begin{array}{l}1.021 \\
(1.45)\end{array}$ \\
\hline Hawke's Bay x collaborative & & & $\begin{array}{c}1.388^{*} \\
(1.80)\end{array}$ & $\begin{array}{c}1.586^{* *} \\
(2.01)\end{array}$ & $\begin{array}{c}1.627^{* *} \\
(2.06)\end{array}$ & $\begin{array}{c}1.642^{* *} \\
(2.11)\end{array}$ \\
\hline Employment: farming & & & & $\begin{array}{l}0.429 \\
(1.28)\end{array}$ & $\begin{array}{l}0.444 \\
(1.31)\end{array}$ & $\begin{array}{l}0.521 \\
(1.56)\end{array}$ \\
\hline Employment: forestry & & & & $\begin{array}{l}0.532 \\
(1.01)\end{array}$ & $\begin{array}{l}0.632 \\
(1.28)\end{array}$ & $\begin{array}{l}0.672 \\
(1.37)\end{array}$ \\
\hline Employment: water/environment & & & & $\begin{array}{l}0.158 \\
(0.23)\end{array}$ & $\begin{array}{l}0.151 \\
(0.23)\end{array}$ & $\begin{array}{l}0.325 \\
(0.48)\end{array}$ \\
\hline Employment: government & & & & $\begin{array}{l}0.367 \\
(0.61)\end{array}$ & $\begin{array}{l}0.324 \\
(0.53)\end{array}$ & $\begin{array}{l}0.478 \\
(0.79)\end{array}$ \\
\hline Female & & & & & $\begin{array}{l}0.147 \\
(0.51)\end{array}$ & $\begin{array}{c}0.0989 \\
(0.35)\end{array}$ \\
\hline Māori & & & & & $\begin{array}{c}-0.785 * \\
(-1.73)\end{array}$ & $\begin{array}{l}-0.611 \\
(-1.32)\end{array}$ \\
\hline Medium/high engagement & & & & & & $\begin{array}{c}-0.800 * * * \\
(-2.61)\end{array}$ \\
\hline Constant & $\begin{array}{c}4.854 * * * \\
(23.52)\end{array}$ & $\begin{array}{c}4.813 * * * \\
(15.51)\end{array}$ & $\begin{array}{c}5.257 * * * \\
(14.62)\end{array}$ & $\begin{array}{c}5.085^{* * *} * \\
(13.38)\end{array}$ & $\begin{array}{c}5.062 * * * \\
(12.66)\end{array}$ & $\begin{array}{c}5.242^{* * *} * \\
(12.75)\end{array}$ \\
\hline $\mathrm{N}$ & 354 & 354 & 354 & 354 & 354 & 354 \\
\hline Collab + (Northland $x$ collab) & & & 0.288 & 0.295 & 0.290 & 0.278 \\
\hline Collab + (Hawke's Bay x collab) & & & 0.741 & $0.880^{*}$ & $0.949 *$ & $0.899 *$ \\
\hline McFadden's pseudo $\mathrm{R}^{2}$ & 0.000114 & 0.00274 & 0.00474 & 0.00719 & 0.00922 & 0.0127 \\
\hline
\end{tabular}

Heteroskedasticity-robust $\mathrm{t}$ statistics are in parentheses.

$* \mathrm{p}<0.10 ; * * \mathrm{p}<0.05 ; * * * \mathrm{p}<0.01$.

Residents of Northland and Waikato did not systematically differ in their perceptions of agreement.

In contrast, respondents with current/previous employment in forestry believed that there is more agreement on freshwater management than others $(\mathrm{p}<0.10)$. In addition, medium or high engagement was associated with greater perceptions of conflict among parties with interest in freshwater management. Again, this last result may stem either from those with higher engagement having additional information or those with perceptions of conflict participating in forums to influence freshwater outcomes. Demographics did not influence perceptions of agreement.

\section{Fairness}

Survey respondents were asked about the extent to which they believe that water management processes are fair. We hypothesized that by including a broad range of stakeholders in the planning process and by reaching consensus, collaboration would be perceived as fairer than other planning approaches. Table 4 reports results analogously as above; again, model 6 is preferred.

The point estimate for fairness was approximately 5 on the $0-10$ scale, with no statistical differences for respondents in Waikato and Northland regardless of whether they live in collaborative catchments. However, respondents from collaborative catchments in Hawke's Bay evaluated the fairness of water management 0.8 points higher than others $(\mathrm{p}<0.01)$, which is $16 \%$ of the mean. Respondents with work experience in forestry and water/ environment also considered management processes to be fairer ( $p<0.01$ and $p<0.10$, respectively) than respondents without such experience. Finally, respondents with medium/high levels of engagement had 0.7 point lower perceptions of fairness $(p<0.05)$ relative to others, consistent with the patterns above. Ceteris paribus, demographics do not impact perceptions of fairness.

\section{Interests}

Last, survey respondents were asked to report the extent to which they believe that their interests and concerns regarding freshwater management are taken into account by the regional council. Table 5 reports the results with the same assumptions and format as the previous tables; model 6 is preferred.

The point estimate for a male, non-Māori respondent who is not engaged in water management issues and who has not worked in the listed industries was 4.8 on the $0-10$ scale, a value that did not differ statistically by region or by catchment. The point estimate for respondents with experience in forestry was 1.1 points higher $(p<0.10)$, which is $23 \%$ of the mean. Conversely, respondents with medium/high engagement with freshwater planning evaluated the extent to which their interests and concerns are taken into account 1.0 points lower than others $(p<0.01)$; 
Table 3. Perceptions of agreement on management of freshwater resources ("Thinking about conflict or agreement between competing interests over water management in your area, using a scale of 0 to 10 where 0 means lots of conflict and 10 means strong agreement, would you say there is conflict or agreement between competing interests over water management in your area?")

\begin{tabular}{|c|c|c|c|c|c|c|}
\hline & (1) & (2) & (3) & (4) & (5) & (6) \\
\hline Collaborative catchment & $\begin{array}{l}0.608 * * \\
(1.97)\end{array}$ & $\begin{array}{c}0.565^{*} \\
(1.85)\end{array}$ & $\begin{array}{l}0.187 \\
(0.30)\end{array}$ & $\begin{array}{l}0.116 \\
(0.19)\end{array}$ & $\begin{array}{l}0.108 \\
(0.18)\end{array}$ & $\begin{array}{c}0.0382 \\
(0.06)\end{array}$ \\
\hline Northland & & $\begin{array}{l}-0.544 \\
(-1.42)\end{array}$ & $\begin{array}{l}-0.760 \\
(-1.42)\end{array}$ & $\begin{array}{l}-0.815 \\
(-1.51)\end{array}$ & $\begin{array}{l}-0.787 \\
(-1.46)\end{array}$ & $\begin{array}{l}-0.850 \\
(-1.54)\end{array}$ \\
\hline Hawke's Bay & & $\begin{array}{c}-1.262 * * * \\
(-2.99)\end{array}$ & $\begin{array}{c}-1.586 * * * \\
(-2.91)\end{array}$ & $\begin{array}{c}-1.612^{* * *} \\
(-2.96)\end{array}$ & $\begin{array}{c}-1.640^{* * *} \\
(-2.99)\end{array}$ & $\begin{array}{c}-1.535 * * * \\
(-2.75)\end{array}$ \\
\hline Northland x collaborative & & & $\begin{array}{l}0.402 \\
(0.53)\end{array}$ & $\begin{array}{l}0.417 \\
(0.55)\end{array}$ & $\begin{array}{l}0.419 \\
(0.55)\end{array}$ & $\begin{array}{l}0.504 \\
(0.66)\end{array}$ \\
\hline Hawke's Bay x collaborative & & & $\begin{array}{l}0.625 \\
(0.74)\end{array}$ & $\begin{array}{l}0.792 \\
(0.94)\end{array}$ & $\begin{array}{l}0.843 \\
(0.99)\end{array}$ & $\begin{array}{l}0.849 \\
(1.00)\end{array}$ \\
\hline Employment: farming & & & & $\begin{array}{l}0.202 \\
(0.64)\end{array}$ & $\begin{array}{l}0.209 \\
(0.65)\end{array}$ & $\begin{array}{l}0.309 \\
(0.98)\end{array}$ \\
\hline Employment: forestry & & & & $\begin{array}{l}0.792 \\
(1.46)\end{array}$ & $\begin{array}{l}0.852 \\
(1.62)\end{array}$ & $\begin{array}{c}0.887 * \\
(1.75)\end{array}$ \\
\hline Employment: water/environment & & & & $\begin{array}{l}0.600 \\
(0.91)\end{array}$ & $\begin{array}{l}0.607 \\
(0.91)\end{array}$ & $\begin{array}{l}0.851 \\
(1.38)\end{array}$ \\
\hline Employment: government & & & & $\begin{array}{c}0.0826 \\
(0.11)\end{array}$ & $\begin{array}{c}0.0969 \\
(0.13)\end{array}$ & $\begin{array}{l}0.267 \\
(0.37)\end{array}$ \\
\hline Female & & & & & $\begin{array}{c}0.0513 \\
(0.17)\end{array}$ & $\begin{array}{c}0.00283 \\
(0.01)\end{array}$ \\
\hline Māori & & & & & $\begin{array}{l}-0.408 \\
(-0.78)\end{array}$ & $\begin{array}{l}-0.143 \\
(-0.27)\end{array}$ \\
\hline Medium/high engagement & & & & & & $\begin{array}{c}-1.124 * * * \\
(-3.04)\end{array}$ \\
\hline Constant & $\begin{array}{l}4.482^{* * * *} \\
(21.30)\end{array}$ & $\begin{array}{c}5.148 * * * \\
(15.01)\end{array}$ & $\begin{array}{c}5.349 * * * \\
(12.53)\end{array}$ & $\begin{array}{c}5.188 * * * \\
(11.41)\end{array}$ & $\begin{array}{c}5.202 * * * \\
(10.58)\end{array}$ & $\begin{array}{c}5.460 * * * \\
(10.85)\end{array}$ \\
\hline $\mathrm{N}$ & 328 & 328 & 328 & 328 & 328 & 328 \\
\hline Collab + (Northland x collab) & & & 0.589 & 0.533 & 0.527 & 0.5422 \\
\hline Collab + (Hawke’s Bay x collab) & & & 0.812 & 0.908 & $0.951^{*}$ & 0.8872 \\
\hline McFadden's pseudo $\mathrm{R}^{2}$ & 0.00246 & 0.00845 & 0.00881 & 0.0121 & 0.0126 & 0.0196 \\
\hline
\end{tabular}

Heteroskedasticity-robust $t$ statistics are in parentheses.

${ }^{*} \mathrm{p}<0.10 ; * \mathrm{p}<0.05 ; * * \mathrm{p}<0.01$.

presumably, this perception influences their decision to become engaged. None of the other explanatory variables impacted perceptions of whether interests and concerns are taken into account.

\section{DISCUSSION}

Sinner et al. (2015) found low awareness of collaborative planning processes among the general public. Given that the collaborative processes in the catchments sampled in this study have yet to reach substantive conclusions, we expected that awareness of these processes would also be low. The survey confirmed this expectation: In catchments with a collaborative process under way, $21 \%$ of respondents said that they are aware that a collaborative process is taking place in their local area, whereas $15 \%$ of people in noncollaborative areas thought that a collaborative process is taking place when it is not.

Whether this low awareness among the general public is a concern depends on the collaborative groups' expectations for how public values should be considered in the planning process and their expectations about the proportion of the public that will take active interest in freshwater management. If the general public is represented in the collaborative group or is expected to have its say through submissions processes after the group has made its recommendations, then low awareness of the collaborative process is probably not a concern. However, if collaborative groups are relying on public input during the process, even if via group members, then the groups should consider whether they are reaching their target audience.

For similar reasons, at this stage, we do not expect a large difference in public perceptions regarding management, agreement, fairness, and interests between collaborative and noncollaborative areas because it may take time for the collaborative processes to reach agreement and for differences in perceptions to emerge. Accordingly, we found no discernible differences between Waikato respondents inside and outside catchments with collaborative processes for any of our four measures. Respondents in Northland had lower perceptions of the management of freshwater than respondents in Waikato, but perceptions of respondents in Northland in the remaining three categories were otherwise statistically indistinguishable from those of respondents in Waikato. Moreover, living in a catchment with a collaborative process did not alter perceptions of any measure among respondents in Northland.

On the other hand, respondents who live in the TANK catchments in Hawke's Bay perceived the regional council to have better management practices for freshwater and perceived that management as being fairer than other Hawke's Bay respondents. 
Table 4. Perceptions of the fairness of processes for water management ("Using a scale from 0 to 10 , where 0 means not fair at all and 10 means very fair, in your opinion, how fair do you think the water management processes are in the [name of regional council] area?")

\begin{tabular}{|c|c|c|c|c|c|c|}
\hline & (1) & $(2)$ & (3) & (4) & $(5)$ & (6) \\
\hline Collaborative catchment & $\begin{array}{l}0.392 \\
(1.40)\end{array}$ & $\begin{array}{l}0.431 \\
(1.55)\end{array}$ & $\begin{array}{l}0.240 \\
(0.43)\end{array}$ & $\begin{array}{l}0.210 \\
(0.38)\end{array}$ & $\begin{array}{l}0.214 \\
(0.38)\end{array}$ & $\begin{array}{l}0.145 \\
(0.26)\end{array}$ \\
\hline Northland & & $\begin{array}{l}-0.569 \\
(-1.62)\end{array}$ & $\begin{array}{l}-0.577 \\
(-1.10)\end{array}$ & $\begin{array}{l}-0.711 \\
(-1.34)\end{array}$ & $\begin{array}{l}-0.700 \\
(-1.32)\end{array}$ & $\begin{array}{l}-0.750 \\
(-1.40)\end{array}$ \\
\hline Hawke's Bay & & $\begin{array}{l}-0.261 \\
(-0.70)\end{array}$ & $\begin{array}{l}-0.556 \\
(-1.04)\end{array}$ & $\begin{array}{l}-0.567 \\
(-1.09)\end{array}$ & $\begin{array}{l}-0.564 \\
(-1.09)\end{array}$ & $\begin{array}{l}-0.511 \\
(-0.99)\end{array}$ \\
\hline Northland $\mathrm{x}$ collaborative & & & $\begin{array}{c}0.0416 \\
(0.06)\end{array}$ & $\begin{array}{c}0.0351 \\
(0.05)\end{array}$ & $\begin{array}{c}0.0307 \\
(0.04)\end{array}$ & $\begin{array}{l}0.106 \\
(0.15)\end{array}$ \\
\hline Hawke's Bay x collaborative & & & $\begin{array}{l}0.570 \\
(0.76)\end{array}$ & $\begin{array}{l}0.677 \\
(0.94)\end{array}$ & $\begin{array}{l}0.670 \\
(0.93)\end{array}$ & $\begin{array}{l}0.673 \\
(0.93)\end{array}$ \\
\hline Employment: farming & & & & $\begin{array}{l}0.311 \\
(1.06)\end{array}$ & $\begin{array}{l}0.299 \\
(1.02)\end{array}$ & $\begin{array}{l}0.399 \\
(1.33)\end{array}$ \\
\hline Employment: forestry & & & & $\begin{array}{c}1.274 * * * \\
(2.79)\end{array}$ & $\begin{array}{c}1.277 * * * \\
(2.79)\end{array}$ & $\begin{array}{c}1.316^{* * *} \\
(2.81)\end{array}$ \\
\hline Employment: water/environment & & & & $\begin{array}{l}0.935 \\
(1.47)\end{array}$ & $\begin{array}{l}0.941 \\
(1.49)\end{array}$ & $\begin{array}{l}1.161^{*} \\
(1.80)\end{array}$ \\
\hline Employment: government & & & & $\begin{array}{l}-0.558 \\
(-0.83)\end{array}$ & $\begin{array}{l}-0.568 \\
(-0.84)\end{array}$ & $\begin{array}{l}-0.449 \\
(-0.66)\end{array}$ \\
\hline Female & & & & & $\begin{array}{c}-0.0403 \\
(-0.15)\end{array}$ & $\begin{array}{c}-0.0760 \\
(-0.28)\end{array}$ \\
\hline Māori & & & & & $\begin{array}{l}-0.113 \\
(-0.32)\end{array}$ & $\begin{array}{c}0.00329 \\
(0.01)\end{array}$ \\
\hline Medium/high engagement & & & & & & $\begin{array}{c}-0.746^{* *} \\
(-2.21)\end{array}$ \\
\hline Constant & $\begin{array}{c}4.757 * * * \\
(23.37)\end{array}$ & $\begin{array}{c}5.068 * * * \\
(15.79)\end{array}$ & $\begin{array}{c}5.166^{* * * *} \\
(12.39)\end{array}$ & $\begin{array}{c}4.973 * * * \\
(11.74)\end{array}$ & $\begin{array}{c}5.007 * * * \\
(11.19)\end{array}$ & $\begin{array}{c}5.176^{* * *} \\
(11.52)\end{array}$ \\
\hline $\mathrm{N}$ & 344 & 344 & 344 & 344 & 344 & 344 \\
\hline Collab + (Northland x collab) & & & 0.282 & 0.245 & 0.245 & 0.251 \\
\hline Collab + (Hawke's Bay x collab) & & & $0.810^{*}$ & $0.887^{*}$ & $0.884^{*}$ & $0.818^{*}$ \\
\hline McFadden's pseudo $\mathrm{R}^{2}$ & 0.00124 & 0.00303 & 0.00354 & 0.0125 & 0.0126 & 0.0161 \\
\hline
\end{tabular}

Heteroskedasticity-robust $\mathrm{t}$ statistics are in parentheses.

$* \mathrm{p}<0.10 ; * * \mathrm{p}<0.05 ; * * * \mathrm{p}<0.01$.

Moreover, although Hawke's Bay respondents perceived more conflict over freshwater than respondents in Waikato, this negative perception was ameliorated among respondents in the TANK catchments.

There may be any number of reasons for differences in perceptions between people in catchments with and without collaborative processes. For example, factors such as high-quality freshwater bodies in publicly visible locations, a homogeneous local population predisposed toward established planning processes, favorable planning outcomes in the recent past, and recent media reports about freshwater issues could influence survey participants' perceptions of freshwater management. Thus, regional conditions may have more influence on perceptions of freshwater management than whether freshwater planning is following a collaborative process. The multivariate regression helps to isolate these factors.

There are also differences in perceptions about freshwater management depending on respondents' levels of participation in freshwater planning: People who are more engaged perceived less agreement (i.e., greater conflict) about freshwater management than others. Participation is also negatively correlated with respondents' perceptions of regional council management, fairness, and confidence that their interests and concerns regarding freshwater would be addressed by the regional council.
It is possible that people who participate more actively in planning processes do so because they are dissatisfied with current practices. However, if higher participation primarily reflects greater understanding and knowledge of freshwater management, then these negative correlations suggest that those who know most about freshwater management are most sceptical, a cause for concern.

To further evaluate the effect of participation in freshwater planning, Table 6 augments model 6 by adding interaction terms for engagement (specifically, collaborative catchment $\mathrm{x}$ engagement, region $\mathrm{x}$ engagement, and region $\mathrm{x}$ collaborative catchment $x$ engagement). The statistical significance of the marginal effect of engagement is reported separately for catchments with and without collaborative planning processes at the bottom of the table.

In all three regions, respondents who demonstrated a medium/ high level of engagement with freshwater planning perceived that regional councils are less effective in freshwater management than respondents with lower levels of engagement. However, this difference existed only in catchments with collaborative processes. Similarly, respondents who are engaged in water management in Northland and Hawke's Bay (but not Waikato) areas with collaborative planning processes perceived that less agreement exists on management of freshwater resources. They were also statistically less likely to believe that their interests and concerns 
Table 5. Perceptions of the extent to which interests and concerns with regard to freshwater are taken into account ("Using a scale from 0 to 10, where 0 means not confident at all and 10 means very confident, if you had concerns about how you, your family, or your business was affected by freshwater management, how confident are you that your interests and concerns would be taken into account by the [name of regional council]?”)

\begin{tabular}{|c|c|c|c|c|c|c|}
\hline & $(1)$ & $(2)$ & (3) & (4) & $(5)$ & (6) \\
\hline Collaborative catchment & $\begin{array}{l}0.434 \\
(1.41)\end{array}$ & $\begin{array}{l}0.441 \\
(1.43)\end{array}$ & $\begin{array}{l}0.265 \\
(0.43)\end{array}$ & $\begin{array}{l}0.269 \\
(0.43)\end{array}$ & $\begin{array}{l}0.339 \\
(0.55)\end{array}$ & $\begin{array}{l}0.225 \\
(0.36)\end{array}$ \\
\hline Northland & & $\begin{array}{l}-0.121 \\
(-0.32)\end{array}$ & $\begin{array}{l}-0.259 \\
(-0.46)\end{array}$ & $\begin{array}{l}-0.341 \\
(-0.60)\end{array}$ & $\begin{array}{l}-0.292 \\
(-0.51)\end{array}$ & $\begin{array}{l}-0.368 \\
(-0.64)\end{array}$ \\
\hline Hawke’s Bay & & $\begin{array}{c}0.0942 \\
(0.22)\end{array}$ & $\begin{array}{c}-0.0322 \\
(-0.05)\end{array}$ & $\begin{array}{c}-0.0512 \\
(-0.09)\end{array}$ & $\begin{array}{c}-0.0526 \\
(-0.09)\end{array}$ & $\begin{array}{l}0.0561 \\
(0.09)\end{array}$ \\
\hline Northland $\mathrm{x}$ collaborative & & & $\begin{array}{l}0.248 \\
(0.33)\end{array}$ & $\begin{array}{l}0.271 \\
(0.36)\end{array}$ & $\begin{array}{l}0.224 \\
(0.29)\end{array}$ & $\begin{array}{l}0.293 \\
(0.39)\end{array}$ \\
\hline Hawke's Bay x collaborative & & & $\begin{array}{l}0.232 \\
(0.27)\end{array}$ & $\begin{array}{l}0.323 \\
(0.38)\end{array}$ & $\begin{array}{l}0.271 \\
(0.32)\end{array}$ & $\begin{array}{l}0.265 \\
(0.32)\end{array}$ \\
\hline Employment: farming & & & & $\begin{array}{l}0.190 \\
(0.59)\end{array}$ & $\begin{array}{l}0.125 \\
(0.40)\end{array}$ & $\begin{array}{l}0.243 \\
(0.76)\end{array}$ \\
\hline Employment: forestry & & & & $\begin{array}{l}1.016^{*} \\
(1.88)\end{array}$ & $\begin{array}{l}1.032^{*} \\
(1.92)\end{array}$ & $\begin{array}{l}1.083^{*} \\
(1.95)\end{array}$ \\
\hline Employment: water/environment & & & & $\begin{array}{c}-0.0355 \\
(-0.05)\end{array}$ & $\begin{array}{c}0.00735 \\
(0.01)\end{array}$ & $\begin{array}{l}0.257 \\
(0.35)\end{array}$ \\
\hline Employment: government & & & & $\begin{array}{l}-0.322 \\
(-0.46)\end{array}$ & $\begin{array}{l}-0.390 \\
(-0.56)\end{array}$ & $\begin{array}{l}-0.261 \\
(-0.38)\end{array}$ \\
\hline Female & & & & & $\begin{array}{l}-0.295 \\
(-0.98)\end{array}$ & $\begin{array}{l}-0.366 \\
(-1.23)\end{array}$ \\
\hline Māori & & & & & $\begin{array}{l}-0.772 \\
(-1.57)\end{array}$ & $\begin{array}{l}-0.573 \\
(-1.17)\end{array}$ \\
\hline Medium/high engagement & & & & & & $\begin{array}{l}-1.043 * * * \\
(-2.89)\end{array}$ \\
\hline Constant & $\begin{array}{c}4.323 * * * \\
(19.39)\end{array}$ & $\begin{array}{c}4.350 * * * \\
(12.45)\end{array}$ & $\begin{array}{c}4.446^{* * * *} \\
(9.80)\end{array}$ & $\begin{array}{c}4.339^{* * *} \\
(9.43)\end{array}$ & $\begin{array}{c}4.567 * * * \\
(9.40)\end{array}$ & $\begin{array}{l}4.819^{* * *} \\
(9.70)\end{array}$ \\
\hline $\mathrm{N}$ & 415 & 415 & 415 & 415 & 415 & 415 \\
\hline $\begin{array}{l}\text { Collab + (Northland x collab) } \\
\text { Collab + (Hawke's Bay x collab) }\end{array}$ & & & $\begin{array}{l}0.513 \\
0.497\end{array}$ & $\begin{array}{l}0.540 \\
0.592\end{array}$ & $\begin{array}{l}0.563 \\
0.610\end{array}$ & $\begin{array}{l}0.518 \\
0.490\end{array}$ \\
\hline McFadden's pseudo $\mathrm{R}^{2}$ & 0.000997 & 0.00118 & 0.00124 & 0.00334 & 0.00518 & 0.00932 \\
\hline
\end{tabular}

Heteroskedasticity-robust $\mathrm{t}$ statistics are in parentheses.

$* \mathrm{p}<0.10 ; * \mathrm{p}<0.05 ; * * * \mathrm{p}<0.01$.

about freshwater are taken into account. In contrast, in areas without collaborative planning processes, there was no statistical difference in perceptions of agreement or interests between engaged respondents and others. Finally, engaged respondents in parts of Northland (but not Waikato or Hawke's Bay) with collaborative processes believed that freshwater management is less fair vis-à-vis other respondents.

The perceptions reported here warrant monitoring as collaborative processes in these regions reach consensus and conclude. If they endure, it brings into question whether collaborative planning as currently practiced in these regions will in fact strengthen local environmental democracy.

\section{CONCLUSION}

Anticipating rule changes to encourage collaborative approaches in freshwater decision making, 6 of New Zealand's 16 regional councils have experimented with collaborative processes. The design and implementation of those collaborative processes vary across regions and are the subject of other studies in this Special Feature. However, the success or failure of those collaborative processes ultimately rests in public acceptance of the processes and their outcomes. As yet, there is little evidence on public perceptions of collaborative approaches to freshwater management.
To address this issue, we used a unique survey of 450 residents of 3 regions in which collaborative processes are under way, Hawke's Bay, Northland, and Waikato, to evaluate public perceptions of collaborative planning processes. Importantly, our survey design included, in each region, respondents living in catchments with collaborative processes as well as respondents in catchments without collaborative processes. This design feature allowed us to better isolate the effects of collaborative processes on perceptions from perceptions of the regional council more generally.

We found that knowledge of collaborative processes for freshwater management is generally low and that living in a catchment with a collaborative process does not significantly impact respondents' perceptions of management, agreement, fairness, or interests in two of the three regions studied. However, relative to Hawke's Bay respondents living outside of the collaborative catchment, respondents inside the collaborative catchment believe that the regional council has better management practices and that their management of freshwater is fairer. Moreover, Hawke's Bay residents living inside the collaborative catchment perceive more agreement over freshwater management than those living outside the collaborative catchment. 
Table 6. Marginal effects of engagement in freshwater issues on perceptions of management, agreement, the extent to which interests and concerns are taken into account, and fairness

\begin{tabular}{|c|c|c|c|c|}
\hline & $\begin{array}{c}\text { (1) } \\
\text { Management }\end{array}$ & $\begin{array}{c}(2) \\
\text { Agreement }\end{array}$ & $\begin{array}{c}\text { (3) } \\
\text { Fairness }\end{array}$ & $\begin{array}{c}\text { (4) } \\
\text { Interests }\end{array}$ \\
\hline Collaborative catchment & $\begin{array}{l}-0.514 \\
(-0.77)\end{array}$ & $\begin{array}{l}0.222 \\
(0.33)\end{array}$ & $\begin{array}{l}0.164 \\
(0.28)\end{array}$ & $\begin{array}{l}0.404 \\
(0.58)\end{array}$ \\
\hline Northland & $\begin{array}{l}-1.180^{*} \\
(-1.89)\end{array}$ & $\begin{array}{l}-0.383 \\
(-0.62)\end{array}$ & $\begin{array}{l}-0.920 \\
(-1.44)\end{array}$ & $\begin{array}{l}-0.517 \\
(-0.75)\end{array}$ \\
\hline Hawke’s Bay & $\begin{array}{l}-0.514 \\
(-0.79)\end{array}$ & $\begin{array}{l}-1.133^{*} \\
(-1.72)\end{array}$ & $\begin{array}{l}-0.817 \\
(-1.35)\end{array}$ & $\begin{array}{l}-0.206 \\
(-0.29)\end{array}$ \\
\hline Northland $\mathrm{x}$ collaborative & $\begin{array}{l}1.232 \\
(1.45)\end{array}$ & $\begin{array}{l}0.545 \\
(0.66)\end{array}$ & $\begin{array}{l}0.561 \\
(0.72)\end{array}$ & $\begin{array}{l}0.654 \\
(0.75)\end{array}$ \\
\hline Hawke's Bay x collaborative & $\begin{array}{c}2.042 * * \\
(2.27)\end{array}$ & $\begin{array}{l}0.897 \\
(0.91)\end{array}$ & $\begin{array}{l}1.000 \\
(1.24)\end{array}$ & $\begin{array}{l}0.810 \\
(0.84)\end{array}$ \\
\hline Medium/high engagement & $\begin{array}{l}-0.591 \\
(-0.92)\end{array}$ & $\begin{array}{l}0.494 \\
(0.49)\end{array}$ & $\begin{array}{l}-0.658 \\
(-0.72)\end{array}$ & $\begin{array}{l}-0.471 \\
(-0.47)\end{array}$ \\
\hline Collaborative $\mathrm{x}$ engagement & $\begin{array}{l}-1.036 \\
(-0.91)\end{array}$ & $\begin{array}{l}-0.473 \\
(-0.30)\end{array}$ & $\begin{array}{c}-0.0584 \\
(-0.04)\end{array}$ & $\begin{array}{l}-0.653 \\
(-0.41)\end{array}$ \\
\hline Northland $\mathrm{x}$ engagement & $\begin{array}{l}1.076 \\
(1.26)\end{array}$ & $\begin{array}{l}-1.701 \\
(-1.33)\end{array}$ & $\begin{array}{l}0.595 \\
(0.53)\end{array}$ & $\begin{array}{l}0.556 \\
(0.48)\end{array}$ \\
\hline Hawke's Bay x engagement & $\begin{array}{l}0.468 \\
(0.46)\end{array}$ & $\begin{array}{l}-1.468 \\
(-1.21)\end{array}$ & $\begin{array}{l}0.812 \\
(0.72)\end{array}$ & $\begin{array}{l}0.504 \\
(0.39)\end{array}$ \\
\hline Northland $\mathrm{x}$ collab $\mathrm{x}$ engage & $\begin{array}{l}-0.567 \\
(-0.40)\end{array}$ & $\begin{array}{l}-0.229 \\
(-0.12)\end{array}$ & $\begin{array}{l}-1.573 \\
(-0.83)\end{array}$ & $\begin{array}{l}-1.599 \\
(-0.86)\end{array}$ \\
\hline Hawke's Bay x collab x engage & $\begin{array}{l}-0.785 \\
(-0.50)\end{array}$ & $\begin{array}{l}-0.196 \\
(-0.10)\end{array}$ & $\begin{array}{l}-0.888 \\
(-0.47)\end{array}$ & $\begin{array}{l}-1.542 \\
(-0.77)\end{array}$ \\
\hline Constant & $\begin{array}{c}5.186 * * * \\
(10.61)\end{array}$ & $\begin{array}{c}4.972 * * * \\
(9.04)\end{array}$ & $\begin{array}{c}5.163 * * * \\
(10.21)\end{array}$ & $\begin{array}{c}4.664 * * * \\
(8.48)\end{array}$ \\
\hline $\mathrm{N}$ & 354 & 328 & 344 & 415 \\
\hline Demographics and employment & YES & YES & YES & YES \\
\hline Engage $+($ Collab $x$ engage $)$ & $-1.627^{*}$ & 0.021 & -0.716 & -1.124 \\
\hline Engage + (Northland $x$ engage $)$ & 0.485 & -1.207 & -0.063 & 0.085 \\
\hline $\begin{array}{l}\text { Engage }+(\text { Northland } x \text { engage })+(\text { collab } x \\
\text { engage })+(\text { Northland } x \text { collab } x \text { engage })\end{array}$ & $-1.118^{*}$ & $-1.909 * * *$ & $-1.694 * * *$ & $-2.167 * * *$ \\
\hline Engage + (Hawke's Bay x engage) & -0.123 & -0.974 & 0.154 & 0.033 \\
\hline $\begin{array}{l}\text { Engage }+(\text { Hawke's Bay x engage })+(\text { collab } x \\
\text { engage })+(\text { Hawke's Bay } x \text { collab } x \text { engage })\end{array}$ & $-1.944^{* * *}$ & $-1.643^{*}$ & -0.792 & $-2.162 * * *$ \\
\hline McFadden's pseudo $\mathrm{R}^{2}$ & 0.0169 & 0.0234 & 0.0193 & 0.0134 \\
\hline
\end{tabular}

Heteroskedasticity-robust $t$ statistics are in parentheses.

${ }^{*} \mathrm{p}<0.10 ;{ }^{* *} \mathrm{p}<0.05 ; * * * \mathrm{p}<0.01$.

We also found that respondents who participate more actively in planning processes have uniformly less favorable perceptions of their council's freshwater management. We recognize the endogeneity concern and understand that people with less favorable perceptions of freshwater management may become involved in planning processes. At the same time, if higher participation reflects greater understanding and knowledge of freshwater management and leads to more negative responses, then these negative correlations are concerning. Similarly, councils may choose to employ collaborative approaches in catchments with the most challenging management problems or where the council is held in low regard. In such cases, it is important to track perceptions over time to see whether collaborative planning can deliver the beneficial outcomes claimed by its proponents.

We thus advocate for further research to better understand the reasons for differences in how regional publics respond to collaborative freshwater planning as well as in-depth interviews with members of the public with higher levels of engagement. We also plan follow-up surveys at regular intervals to identify whether public perceptions change as collaborative processes conclude.
${ }^{[1]}$ The lead author of this paper was heavily involved in designing the TANK collaborative process and continues to advise the Hawke's Bay Regional Council on the process.

${ }^{[2]}$ There is no goodness-of-fit measure analogous to the $\mathrm{R}^{2}$ statistic in OLS, and McFadden's pseudo $\mathrm{R}^{2}$ should not be interpreted as such. However, this measure can help to choose among different specifications. See Veall and Zimmerman (1994).

Responses to this article can be read online at: http://www.ecologyandsociety.org/issues/responses. $\mathrm{php} / 8851$

\section{Acknowledgments:}

The authors gratefully acknowledge colleagues in Hawke's Bay, Northland, and Waikato regional councils for sharing information about their collaborative processes. We also thank UMR Research for superb survey enumeration. 


\section{LITERATURE CITED}

Amemiya, T. 1973. Regression analysis when the dependent variable is truncated normal. Econometrica 41(6):997-1016. http://dx.doi.org/10.2307/1914031

Ansell, C., and A. Gash. 2008. Collaborative governance in theory and practice. Journal of Public Administration Research and Theory 18(4):543-571. http://dx.doi.org/10.1093/jopart/mum032

Cradock-Henry, N. 2013. Evaluating a collaborative process. Policy Brief No. 2. Landcare Research, Lincoln, New Zealand.

Dietz, T., E. Ostrom, and P. S. Stern. 2003. The struggle to govern the commons. Science 302(5652):1907-1912. http://dx.doi. org/10.1126/science.1091015

Environmental Protection Authority. 2015. Tukituki Catchment Proposal. Environmental Protection Authority, Wellington, New Zealand. [online] URL: http://www.epa.govt.nz/Resourcemanagement/previous/Tukituki/Pages/default.aspx

Hawke's Bay Regional Council (HBRC). 2015. TANK Project. HBRC, Napier, New Zealand. [online] URL: http://www.hbrc. govt.nz/hawkes-bay/projects/tank/about-tank/

Hughey, K. F. D., G. Kerr, and R. Cullen. 2013. Public perceptions of New Zealand's environment 2013. EOS Ecology, Christchurch, New Zealand.

Innes J. E., and D. E. Booher. 2010. Planning with complexity: an introduction to collaborative rationality for public policy. Routledge, Abingdon, UK.

Kempf A. M., and P. L. Remington. 2007. New challenges for telephone survey research in the twenty-first century. Annual Review of Public Health 28:113-126. http://dx.doi.org/10.1146/ annurev.publhealth.28.021406.144059

Land and Water Forum. 2012. Second report of the Land and Water Forum: setting limits for water quality and quantity, and freshwater policy-and plan-making through collaboration. Land and Water Trust, Wellington, New Zealand.

Link, M. W., M. P. Battaglia, M. R. Franke, L. Osborn, and A. H. Mokdad. 2007. Reaching the U.S. cell phone generation comparison of cell phone survey results with an ongoing landline telephone survey. Public Opinion Quarterly 71(5):814-839. http:// dx.doi.org/10.1093/poq/nfm051

Ministry for the Environment (MfE). 2013. Freshwater reform 2013 and beyond. Ministry for the Environment, Wellington, New Zealand.

Ministry for the Environment (MfE). 2014. National policy statement for freshwater management 2014. Ministry for the Environment, Wellington, New Zealand.

Northland Regional Council. 2016. Regional Policy Statement for Northland. Northland Regional Council,Whangãrei, New Zealand. [online] URL: http://www.nrc.govt.nz/resources/?url=/ Resource-Library-Summary/Plans-and-Policies/Regional-PolicyStatement/Regional-Policy-Statement/

Pahl-Wostl, C., D. Tàbara, R. Bouwen, M. Craps, A. Dewulf, E. Mostert, D. Ridder, and T. Taillieu. 2008. The importance of social learning and culture for sustainable water management. Ecological Economics 64(3):484-495. http://dx.doi.org/10.1016/j. ecolecon.2007.08.007

Scholz, J. T., and B. Stiftel. 2005. Adaptive governance and water conflict: new institutions for collaborative planning. RFF Press, Washington, D.C., USA.

Sinner, J., M. Newton, and R. Duncan. 2015. Representation and legitimacy in collaborative freshwater planning. Cawthron Report No. 2787. Cawthron, Nelson, New Zealand. [online] URL: http:// www.cawthron.org.nz/publication/science-reports/representationand-legitimacy-collaborative-freshwater-planning-stakeholderperspectives-canterbury-l

Veall, M. R., and K. F. Zimmermann. 1994. Goodness of fit measures in the Tobit model. Oxford Bulletin of Economics and Statistics 56(4):485-499. http://dx.doi.org/10.1111/j.1468-0084.1994. $\underline{\text { tb00022.x }}$

Waikato Regional Council (WRC). 2015. Healthy Rivers: Plan for Change/Wai Ora: He Rautaki Whakapaipai. WRC, Hamilton, New Zealand. [online] URL: http://www.waikatoregion.govt.nz/ Council/Policy-and-plans/Plans-under-development/Healthy-Rivers--Plan-for-Change/

Waikato Regional Council (WRC). 2016. Water allocation variation. WRC, Hamilton, New Zealand. [online] URL: http:// www.waikatoregion.govt.nz/waterallocation/ 